\title{
Measurement of Radon Exhalation Rate, Annual Effective Dose and Radium Activity from Marine Sediments Samples Collected From Abian Beach, Aden Gulf, Yemen
}

\author{
Fuad Abdo AS-Subaihi, ${ }^{1,}$, Tahir Abdullah Abdulgabar Salem ${ }^{2}$ \\ ${ }^{1}$ Physics Department, Faculty of Science and Education-Sabir, Aden University, Aden, Yemen \\ ${ }^{2}$ Chemistry Departments, Faculty of Science and Education-Sabir, Aden University, Aden, Yemen
}

Email address:

fabdo11@yahoo.com (F. A. AS-Subaihi)

${ }^{*}$ Corresponding author

To cite this article:

Fuad Abdo AS-Subaihi, Tahir Abdullah Abdulgabar Salem. Measurement of Radon Exhalation Rate, Annual Effective Dose and Radium Activity from Marine Sediments Samples Collected From Abian Beach, Aden Gulf, Yemen. Radiation Science and Technology.

Vol. 6, No. 2, 2020, pp. 19-26. doi: 10.11648/j.rst.20200602.12

Received: March 24, 2020; Accepted: April 27, 2020; Published: July 28, 2020

\begin{abstract}
The behavior of radon in marine sediments collected from Abian beach, Abian Governorate, Aden Gulf, Yemen, was studied by using Alpha Guard PQ2000 PRO radon detector. The activity concentration of radon in the sediments was found to be ranging from 64.84 to $166.93 \pm 11.85 \mathrm{~Bq} \cdot \mathrm{m}^{-3}$ with mean value $103.88 \pm 8.80 \mathrm{~Bq} \cdot \mathrm{m}^{-3}$. The radium content in the sediments ranged from 20.01 to $56.06 \mathrm{Bqkg}^{-1}$ with mean value $33.51 \mathrm{Bqkg}^{-1}$, while the area exhalation rate of ${ }^{222} \mathrm{Rn}$ ranged from 6.73 to $18.49 \mathrm{Bqm}^{-2} \mathrm{~h}^{-1}$ with mean value $11.22 \mathrm{Bqm}^{-2} \mathrm{~h}^{-1}$ also the mass exhalation rate of ${ }^{222} \mathrm{Rn}$ ranged from 0.151 to $0.424 \mathrm{Bqkg}$ ${ }^{1} \mathrm{~h}^{-1}$ with mean value $0.253 \mathrm{Bqkg}^{-1} \mathrm{~h}^{-1}$, respectively for the studied samples of marine sediments. The annual effective dose was found to be ranging from 1.63 to $4.21 \mathrm{mSvy}^{-1}$, with an average of $2.62 \mathrm{mSvy}^{-1}$. Average value of radon concentrations from marine sediments samples were compared with other literature values.
\end{abstract}

Keywords: Beach Samples, Radium Content, Radon Exhalation Rates, (Alpha Guard), Annual Absorbed Dose Rate

\section{Introduction}

${ }^{226} \mathrm{Ra}$ is a radioactive element existed in soil, rock, sand, water, animals and plants. ${ }^{226} \mathrm{Ra}$ has entered the human body from the soil by vegetarian food, its (like calcium) concentrated in the bones. This led to bombard the bone marrow and mutate tissue. Subsequently, ${ }^{226} \mathrm{Ra}$ can Cause many health hazards like anemia, sores, bone cancer and other problems.

${ }^{226} \mathrm{Ra}$ is the parent of ${ }^{222} \mathrm{Rn}$, after decay ${ }^{226} \mathrm{Ra},{ }^{222} \mathrm{Rn}$ gas distribution in soil, rock, water and sediments $[1,2]$. Radon is a natural radioactive gas which has no odor, color, or taste. Therefore, it can only be detected with special equipment. Radon is one of the most radioactive and toxic gases. According to the International Commission on Radiological Protection, $40 \%-75 \%$ of exposure of human by natural radioactive sources comes from radon and its daughter nucleus. Radon is a known carcinogenic agent, and being viewed by the World Health Organization (WHO) as the leading reason of lung cancer after smoking [3, 4]. Radon decays into its daughters giving tiny radioactive particles. When inhaled, these radioactive particles can damage the cells that line the lung. Long-term exposure to radon can lead to lung cancer; the only cancer is proven to be associated with inhaling radon. The daughters are solid particles and when they are inhaled they release radiation (alpha and beta) into the lungs, which can potentially cause cancerous cell growth (in the lungs) [5, 6]. When the atmosphere contains ${ }^{222} \mathrm{Rn}$ gas and its decay daughters, the bronchial epithelium received the big part of ionizing radiation, in addition, the extra thoracic airways and the skin may receive good dose, also low dose may receive to the kidney and bone marrow, while ${ }^{222} \mathrm{Rn}$ dissolved in drinking water may effect on the stomach. Many radionuclides in sediments transference are contributing to global collective doses [7, 8]. Therefore, monitor of the pollution in sediments was used widespread and trace pollution sources. ${ }^{222} \mathrm{Rn}$ produced primarily in sediment by the decay of ${ }^{226} \mathrm{Ra}$. A fraction of the radon which 
is produced in sediments will escape to the overlying water column, leaving a deficiency of radon in sediments, so that the activity ratio of radon to radium in less than one. Once radon is in water column, it is mixed vertically and will either decay there or escape to the atmosphere [9, 10]. The measurement of radon flux from soil surface is a useful tool for the assessment of radon prone areas and monitoring of radon released from uranium mining, so it is necessary to study the transfer through porous soils Due to radon low concentration in the environment and its chemical inactivity, its activity concentration can be determined using some specialized equipment. This devices measures number of alpha-particles emitted from some kind of samples [11, 12].

In measurements the radon monitor Alpha Guard
(Saphymo, DE) was used. It determines radon specific activity concentration and, simultaneously, air temperature, pressure and humidity. It has optimal sensitivity coming to $5 \mathrm{cpm}$ at $100 \mathrm{~Bq} / \mathrm{m}^{3}$ and linear response from 2-2 000 $000 \mathrm{~Bq} / \mathrm{m}^{3}$. This set consists of the radon monitor and an air pump in the basic version [13].

The aim of the present work provides database about ${ }^{226} \mathrm{Ra}$ concentration and ${ }^{222} \mathrm{Rn}$ exhalation rate in terms of area and mass in sediments of Abian beach, Aden Gulf, Yemen using Alpha Guard Technique. This data can be used as a reference data for future studies and it may be useful for complete radioactivity mapping for Yemen republic. The map of studied area is shown in Figure 1.

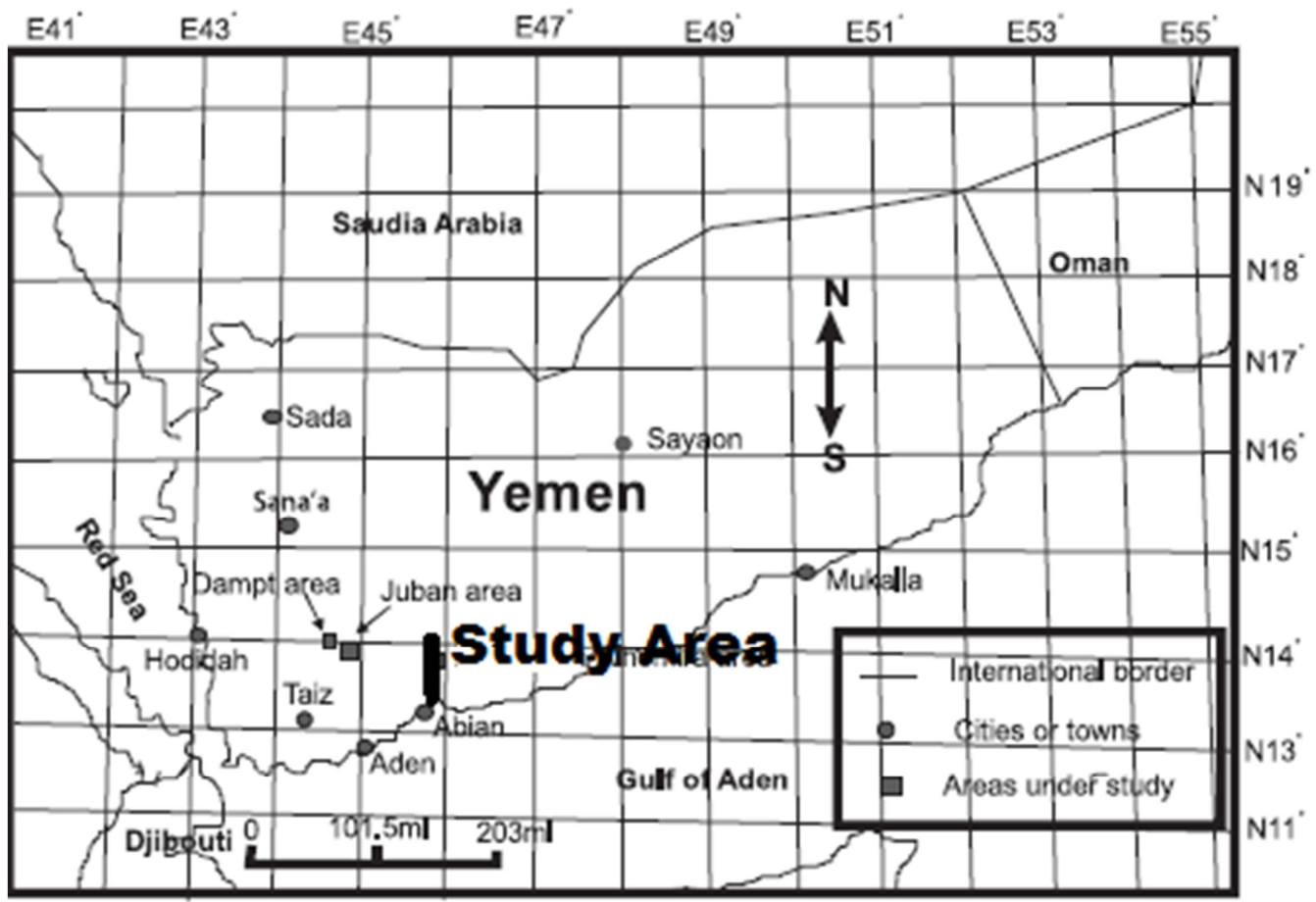

Figure 1. Map of the study area

\section{Materials and Methods}

\subsection{Sampling and Samples Preparation}

Twenty three sand beach sediment samples have been collected from predetermined undisturbed areas alongside the coast of Abian beach, Aden Gulf, Yemen during low-tide. At each of the sample sites, a sampling area of $1 \mathrm{~m}^{2}$ was considered, where five wet samples were taken, each weighing about $1 \mathrm{~kg}$. Four samples were taken from the corners of the site and the fifth was from the center. The sediment samples were taken at depth of $5 \mathrm{~cm}$ from the surface; the samples were collected using Grab sample equipment. Then separated from the contamination materials and air-dried at room temperature for a week, then dried to $110^{\circ} \mathrm{C}$, milled and sieved through $0.2 \mathrm{~mm}$ sieve. The dried samples were put inside cylindrical can. The cans were sealed, gas-tight and stored for four weeks for secular equilibrium [14].

\subsection{Measurement of Radon Gas Concentrations}

Ionization chamber Alpha Guard PQ2000PRO along with the additional special equipment Aqua KIT was used for determining ${ }^{222} \mathrm{Rn}$ exhalation activity concentration in sand beach samples. The background of empty set-up was measured for a few minutes before every sample measuring. About $200 \mathrm{~g}$ of sample was put into the degassing vessel. The Alpha pump was switched on with the flow rate $1 \mathrm{dm}^{3}$ per minute and 10 min flow, so ${ }^{222} \mathrm{Rn}$ activity concentration will be recorded every 10 minute. The advantage of this system is that it is calibrated by the manufacturer and provided a 5-year warranty $[15,16,13]$. Schematic diagram showing the active setup used for the exhalation measurements of samples with Alpha Guard is given in Figure 2.

At equilibrium state, the final activity of exhaled radon inside that container is calculated as follows: 


$$
\mathrm{A}_{\mathrm{t}}\left(\text { Bq. } \mathrm{kg}^{-1}\right)=\mathrm{A}_{0}\left(1-\mathrm{e}^{-\lambda \mathrm{t}}\right)
$$

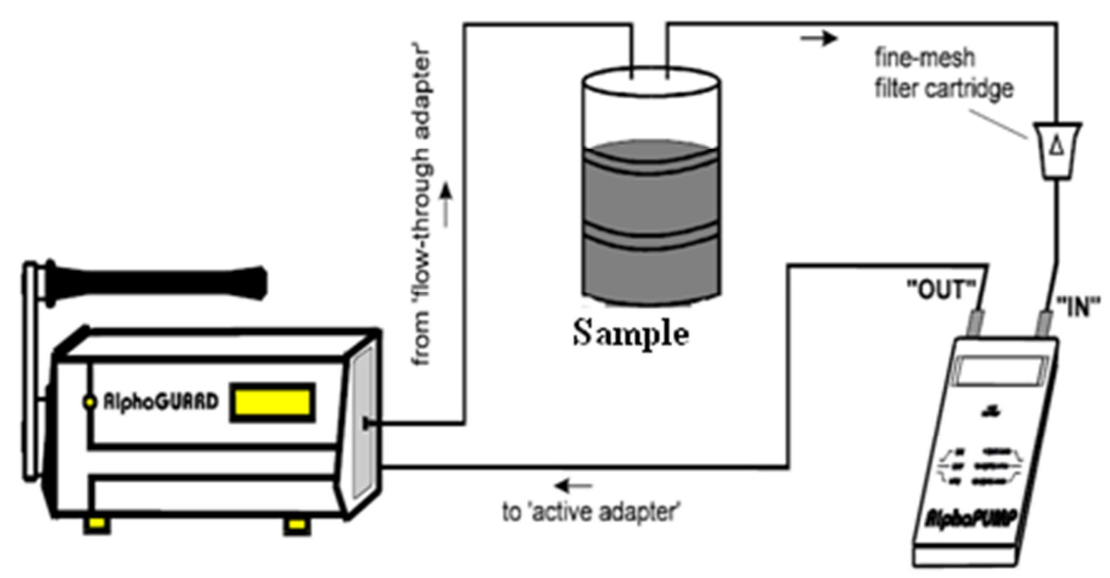

Where $\lambda$ is the decay constant of the radon nuclide and $\mathrm{A}_{0}$ is the final value of the activity concentration, at $\mathrm{t} \approx 7 \mathrm{~T}_{1 / 2}$.

Figure 2. Schematic diagram showing the active setup used for the exhalation measurements of samples with Alpha GUAD.

\subsection{Calculation of Radon Exhalation Rate in Sand Beach Samples}

The radon exhalation rate per unit area of the sample $\mathrm{E}_{\mathrm{A}}$ in $\left(\mathrm{Bq} \cdot \mathrm{m}^{-2} \cdot \mathrm{h}^{-1}\right)$ is calculated using the following formula:

$$
\mathrm{E}_{\mathrm{A}}\left(\mathrm{Bqm}^{-2} \mathrm{~h}^{-1}\right)=\mathrm{A}_{0} \lambda\left(\frac{\mathrm{V}}{\mathrm{F}}\right)
$$

Where $\mathrm{V}$ is the volume of the emanation container $(2400 \times$ $10^{-6} \mathrm{~m}^{3}$ ) and $\mathrm{F}$ is the total surface area of the sample $\left(0.0113 \mathrm{~m}^{2}\right)$, which equals the cross-sectional area of the emanation container.

The radon exhalation rate in terms of mass $E_{m}$ in $\left(\mathrm{Bq} \cdot \mathrm{kg}^{-1} \cdot \mathrm{h}^{-1}\right)$ is calculated using the following formula:

$$
\mathrm{E}_{\mathrm{M}}\left(\mathrm{Bqkg}^{-1} \mathrm{~h}^{-1}\right)=\mathrm{A}_{0} \lambda\left(\frac{\mathrm{v}}{\mathrm{M}}\right)
$$

Where, $m$ is the mass of the sample $[16,17]$.

The effective radium content of the sand beach samples $C_{R a}$ was calculated by using the following relation:

$$
\mathrm{C}_{R a}\left(\mathrm{~Bq} \cdot \mathrm{kg}^{-1}\right)=\left(\frac{\mathrm{E}_{\mathrm{M}}}{\lambda}\right)
$$

Where $\mathrm{C}_{\mathrm{Ra}}\left(\mathrm{Bq} \cdot \mathrm{Kg}^{-1}\right)$ is the effective radium content of the sample, and $E_{M}$ is the radon exhalation rate per unit mass of the sample [17].

The annual effective dose $E_{R n}$ was calculated using the following equation $[18,20]$ :

$$
E_{R n}\left(m S v y{ }^{-1}\right)=C_{R n} \times Q_{f} \times E_{f} \times D_{f} \times 24 h \times 365 \times 10^{-6}
$$

Where $\mathrm{C}_{\mathrm{Rn}}$ is the measured ${ }^{222} \mathrm{Rn}$ concentration $\left(\mathrm{Bqm}^{-3}\right)$, $\left(D_{f}\right)$ is the conversion factor (effective dose received by adults per unit ${ }^{222} \mathrm{Rn}$ activity per unit of air volume) of 9.0 $\mathrm{nSvh}^{-1}$ per Bqm ${ }^{-3},\left(\mathrm{E}_{\mathrm{f}}\right)$ is the equilibrium factor that equal to $0.4,\left(\mathrm{Q}_{\mathrm{f}}\right)$ is the indoor occupancy factor which equal to 0.8 .

\section{Result and Discussion}

The activity concentrations of radon and the annual effective doses from sediment samples from Abian beach, Aden Gulf, Yemen are given in Table 1. The activity concentration of radon gas ranged from 64.84 to 166.93 Bq. $\mathrm{m}^{-3}$ with mean values $103.88 \pm 10.2$ Bq. $\mathrm{m}^{-3}$ the mean value of the activity concentration of radon is lower than the worldwide value of $300 \mathrm{~Bq} / \mathrm{m}^{3}$, which is given in IAEA, 2018, and the annual effective dose ranged from 1.63 to $4.21 \mathrm{mSvy}^{-}$ ${ }^{1}$ with mean value $2.62 \pm 1.621 \mathrm{mSvy}^{-1}$. The annual effective dose was within the allowed limits if compared to the recommended effective annual dose by ICRP, 2007 which was $3-10 \mathrm{mSv} \cdot \mathrm{y}^{-1}$ for all samples and all regions that were selected in the present search $[19,20]$. The mean values of the annual effective dose in this study were $2.62 \mathrm{mSvy}^{-1}$ which it is lower than the permissible limits recommended by ICRP (2010).

Figures 3 and 4 shows the variations of radon concentrations and annual effective doses at different sampling locations. It can be seen from the results that marine sediments radon concentration varies significantly among samples from the sampling location to another throughout the study area. The variation of radon concentration could be attributed to different types of activities for space and different concentration of radioactive material in earth's crust [21]. On the other hand, variation among the activity concentrations of radon of the collected samples from different locations may be due to the continuous wave action, where the high tide may lead to the deposition of radionuclides in sediments such as radium and uranium along the shoreline [22].

In general, the soil type and the characteristics of the surface sediment in this region are different from one site to another [23]. The range and mean values for the surface and mass radon exhalation rates, $\mathrm{E}_{\mathrm{A}}$ and $\mathrm{E}_{\mathrm{M}}$, obtained in these measurements are shown in Table 2. The results show that the surface and mass exhalation rates of radon varies from 6.73 to $18.49 \mathrm{Bqm}^{-2} \mathrm{~h}^{-1}$ with mean value $11.22 \mathrm{Bqm}^{-2} \mathrm{~h}^{-1}$ and from 0.15 to $0.42 \mathrm{Bqkg}^{-1} \mathrm{~h}^{-1}$ with mean value $0.25 \mathrm{~Bq} \mathrm{~kg}^{-1} \mathrm{~h}^{-1}$, respectively in locations $\mathrm{D}_{2}$ and $\mathrm{D}_{8}$. The highest values of 
surface and mass exhalation rates of radon of $18.49 \mathrm{Bqm}^{-2} \mathrm{~h}^{-1}$ and $0.42 \mathrm{Bqkg}^{-1} \mathrm{~h}^{-1}$, respectively. However average value for surface exhalation rates of radon are also quite below the world average of $57,600 \mathrm{mBqm}^{-2} \mathrm{~h}^{-1}$ and hence will not cause any health hazards to residents [22]. It is clear to see that the surface and mass exhalation rates vary from point to point as shown in Figures 5 and 6 and are strongly related to the radon concentration value of the study material. It seems that some of the most important parameters that determine the intensity of radon exhalation from the sediment samples are radium content of the sediment samples [24]. The radium content in the sediments ranged from 20.01 to $56.06 \mathrm{Bqkg}^{-1}$ with mean value $33.51 \mathrm{Bqkg}^{-1}$. Figure 7 shows the variations of the radium content at different sampling locations. The values of radium content determined in sediment are within the permissible value $30 \mathrm{Bqkg}^{-1}$, which is acceptable for safe use as recorded by the recommendation from the Organization for Economic Cooperation and Development "OECD" [25]. These results are given in Table 2. It was noticed that, surface exhalation rate $\mathrm{E}_{\mathrm{A}}$, mass exhalation rate $\mathrm{E}_{\mathrm{M}}$ and radium content are increase with radon concentration. Thus, results show that the area is safe as far the health hazard effects are concerned. It is very important to notice that, this study is constitute the data baseline for the surface and mass exhalation rates in addition to the annual effective dose due to radon from marine sediment samples.

Table 1. Locations, radon concentrations and annual effective doses in sediments samples.

\begin{tabular}{|c|c|c|c|c|}
\hline Samples Code & Latitude & Longitude & $\mathrm{C}_{\mathrm{Rn}}\left(\mathrm{Bq} \cdot \mathrm{m}^{-3}\right)$ & $E_{R n}\left(m S v y^{-1}\right)$ \\
\hline D1 & $12^{\circ} 53^{\prime} 36.1^{\prime \prime}$ & $44^{\circ} 54^{\prime} 32.0^{\prime \prime}$ & $127.13 \pm 11.08$ & 3.21 \\
\hline D2 & $12^{\circ} 56^{\prime} 80.9^{\prime \prime}$ & $45^{\circ} 06^{\prime} 12.9^{\prime \prime}$ & $166.93 \pm 11.85$ & 4.21 \\
\hline D3 & $12^{\circ} 57^{\prime} 31.4^{\prime \prime}$ & $45^{\circ} 06^{\prime} 31.9^{\prime \prime}$ & $131.28 \pm 11.75$ & 3.31 \\
\hline D4 & $12^{\circ} 57^{\prime} 58.9^{\prime \prime}$ & $45^{\circ} 06^{\prime} 72.3^{\prime \prime}$ & $123.82 \pm 9.33$ & 3.12 \\
\hline D5 & $12^{\circ} 58^{\prime} 03.0^{\prime \prime}$ & $45^{\circ} 07^{\prime} 07.0^{\prime \prime}$ & $103.13 \pm 10.42$ & 2.60 \\
\hline D6 & $12^{\circ} 53^{\prime} 61.9^{\prime \prime}$ & $45^{\circ} 07^{\prime} 69.4^{\prime \prime}$ & $134.23 \pm 12.05$ & 3.39 \\
\hline D7 & $12^{\circ} 59^{\prime} 08.0^{\prime \prime}$ & $45^{\circ} 08^{\prime} 29.6^{\prime \prime}$ & $100.95 \pm 9.12$ & 2.55 \\
\hline D9 & $12^{\circ} 59^{\prime} 71.7^{\prime \prime}$ & $45^{\circ} 09^{\prime} 36.9^{\prime \prime}$ & $86.23 \pm 7.08$ & 2.17 \\
\hline D10 & $12^{\circ} 59^{\prime} 97.6^{\prime \prime}$ & $45^{\circ} 09^{\prime} 90.6^{\prime \prime}$ & $93.45 \pm 7.17$ & 2.36 \\
\hline D11 & $13^{\circ} 00^{\prime} 37.8^{\prime \prime}$ & $45^{\circ} 10^{\prime} 82.3^{\prime \prime}$ & $145.63 \pm 11.79$ & 3.67 \\
\hline D12 & $13^{\circ} 00^{\prime} 80.2^{\prime \prime}$ & $45^{\circ} 11^{\prime} 90.7 "$ & $74.80 \pm 7.39$ & 1.89 \\
\hline D13 & $13^{\circ} 01^{\prime} 17.5^{\prime \prime}$ & $45^{\circ} 12^{\prime} 93.9^{\prime \prime}$ & $77.55 \pm 7.10$ & 1.96 \\
\hline D14 & $13^{\circ} 01^{\prime} 47.8^{\prime \prime}$ & $45^{\circ} 13^{\prime} 89.7^{\prime \prime}$ & $81.76 \pm 7.29$ & 2.06 \\
\hline D15 & $13^{\circ} 01^{\prime} 78.6^{\prime \prime}$ & $45^{\circ} 14^{\prime} 67.4^{\prime \prime}$ & $81.97 \pm 6.38$ & 2.07 \\
\hline D18 & $13^{\circ} 04^{\prime} 63.2^{\prime \prime}$ & $45^{\circ} 24^{\prime} 22.7^{\prime \prime}$ & $103.26 \pm 6.48$ & 2.60 \\
\hline D19 & $13^{\circ} 04^{\prime} 00^{\prime \prime}$ & $45^{\circ} 23^{\prime} .042^{\prime \prime}$ & $94.59 \pm 7.94$ & 2.39 \\
\hline D20 & $13^{\circ} 03^{\prime} 19.7^{\prime \prime}$ & $45^{\circ} 22^{\prime} 03.1^{\prime \prime}$ & $123.27 \pm 10.69$ & 3.11 \\
\hline D21 & $13^{\circ} 02^{\prime} .506^{\prime \prime}$ & $45^{\circ} 17^{\prime} 84.1^{\prime \prime}$ & $115.99 \pm 11.48$ & 2.93 \\
\hline D22 & $13^{\circ} 02^{\prime} 42.8^{\prime \prime}$ & $45^{\circ} 17^{\prime} 43.3^{\prime \prime}$ & $124.32 \pm 8.12$ & 3.14 \\
\hline D23 & $13^{\circ} 02^{\prime} 21.7^{\prime \prime}$ & $45^{\circ} 16^{\prime} 52.2^{\prime \prime}$ & $75.12 \pm 6.63$ & 1.89 \\
\hline Minimum & & & $64.84 \pm 6.23$ & 1.635 \\
\hline Maximum & & & $166.93 \pm 11.85$ & 4.211 \\
\hline Mean value & & & $103.88 \pm 8.80$ & 2.62 \\
\hline
\end{tabular}

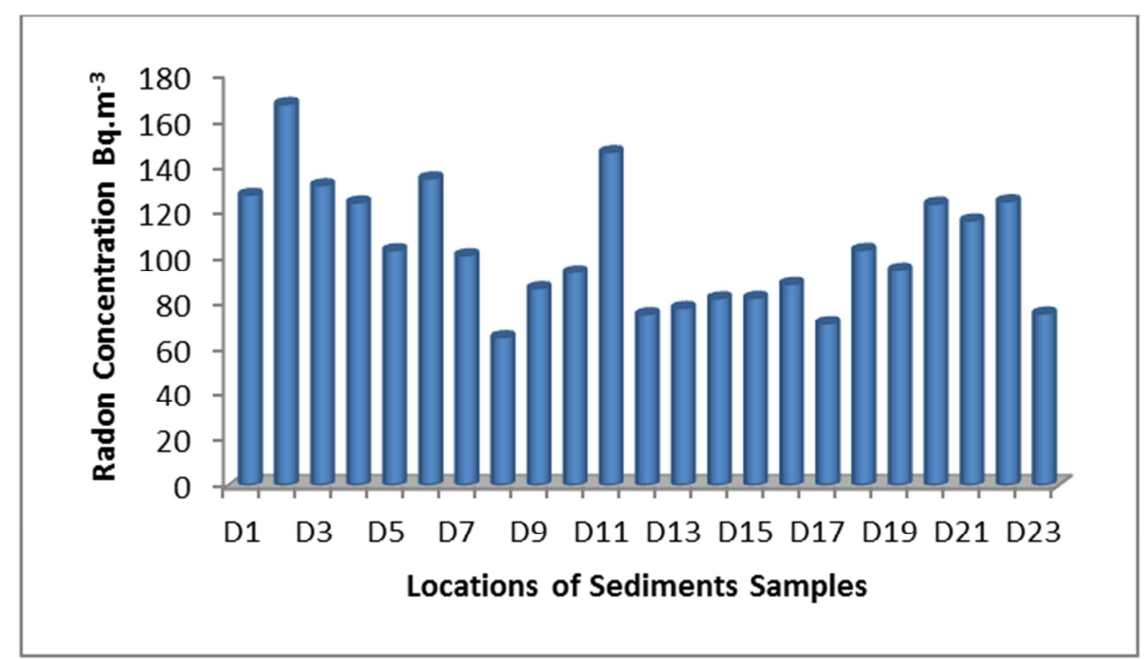

Figure 3. Variation of radon concentration at different locations of sediments samples collected from different sites along the Abian beach. 


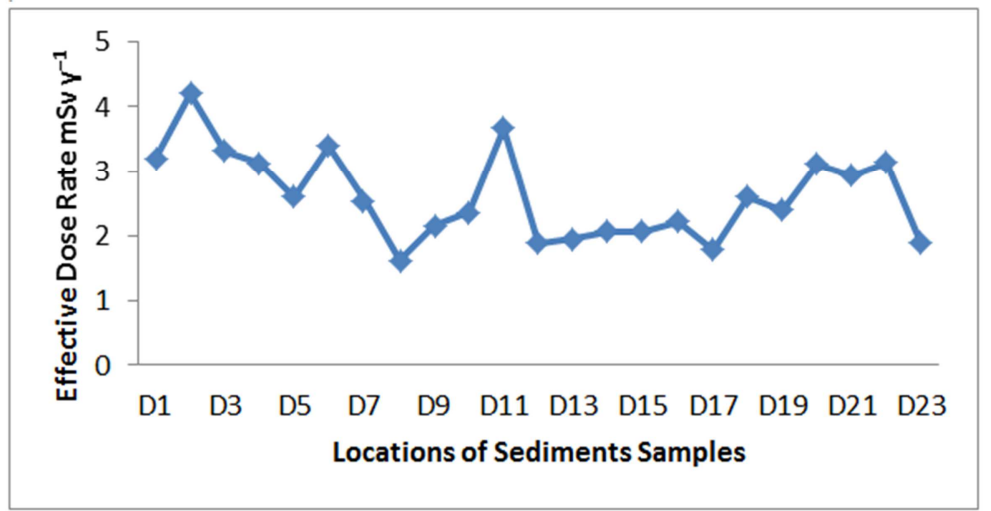

Figure 4. Variation of the annual effective dose with the locations of sediments samples collected from different sites along the Abian beach.

Table 2. The radium content in $B \mathrm{~kg}^{-1}$, mass exhalation rate and area exhalation rate in sediments samples.

\begin{tabular}{|c|c|c|c|}
\hline Samples code & Effective Radium $\left(\mathrm{Bq} \cdot \mathrm{kg}^{-1}\right)$ & Radon mass Exhalation rate in Bq.kg-1 $\mathrm{h}^{-1}$ & Radon Exhalation Rate per unit area $\mathrm{Bq} \cdot \mathrm{m}^{-2} \cdot \mathrm{h}^{-1}$ \\
\hline D1 & 43.27 & 0.327 & 13.90 \\
\hline D2 & 56.06 & 0.424 & 18.49 \\
\hline D3 & 44.39 & 0.336 & 14.38 \\
\hline D4 & 45.34 & 0.343 & 13.52 \\
\hline D5 & 34.20 & 0.258 & 11.13 \\
\hline D6 & 45.98 & 0.347 & 14.72 \\
\hline D7 & 32.83 & 0.248 & 10.88 \\
\hline D8 & 20.01 & 0.151 & 6.73 \\
\hline D9 & 27.80 & 0.210 & 9.18 \\
\hline D10 & 29.89 & 0.226 & 10.02 \\
\hline D11 & 43.39 & 0.328 & 16.04 \\
\hline D12 & 22.71 & 0.172 & 7.87 \\
\hline D13 & 25.48 & 0.193 & 8.18 \\
\hline D14 & 25.50 & 0.193 & 8.67 \\
\hline D15 & 26.66 & 0.201 & 8.69 \\
\hline D16 & 28.13 & 0.213 & 9.39 \\
\hline D17 & 21.74 & 0.164 & 7.42 \\
\hline D18 & 31.07 & 0.235 & 11.15 \\
\hline D19 & 30.13 & 0.228 & 10.15 \\
\hline D20 & 37.73 & 0.285 & 13.46 \\
\hline D21 & 36.47 & 0.276 & 12.62 \\
\hline D22 & 38.77 & 0.293 & 13.58 \\
\hline D23 & 23.17 & 0.175 & 7.90 \\
\hline Minimum & 20.01 & 0.151 & 6.73 \\
\hline Maximum & 56.06 & 0.424 & 18.49 \\
\hline Mean value & 33.51 & 0.253 & 11.22 \\
\hline
\end{tabular}

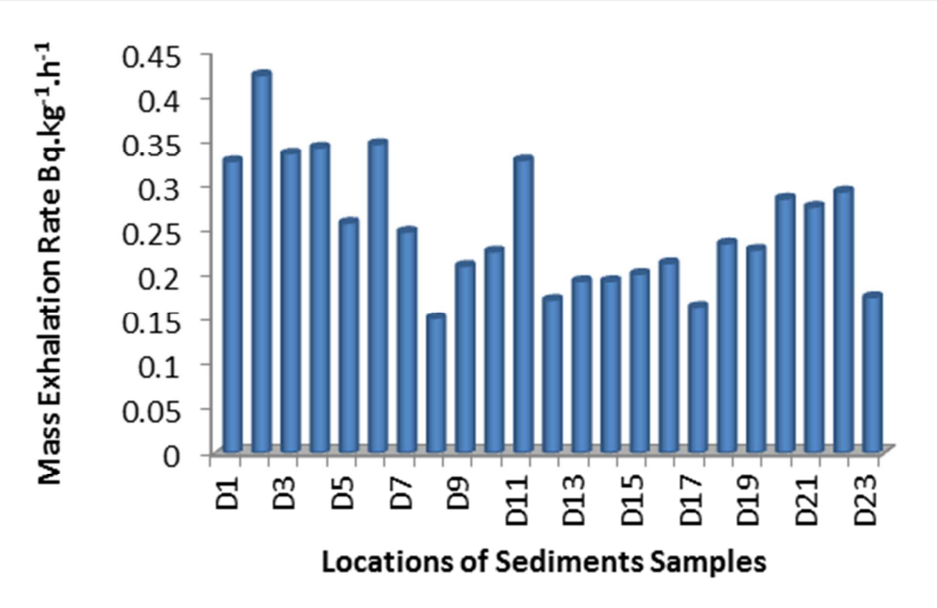

Figure 5. Variation of Mass Exhalation Rate at different locations of sediments samples collected from different sites along the Abian beach. 


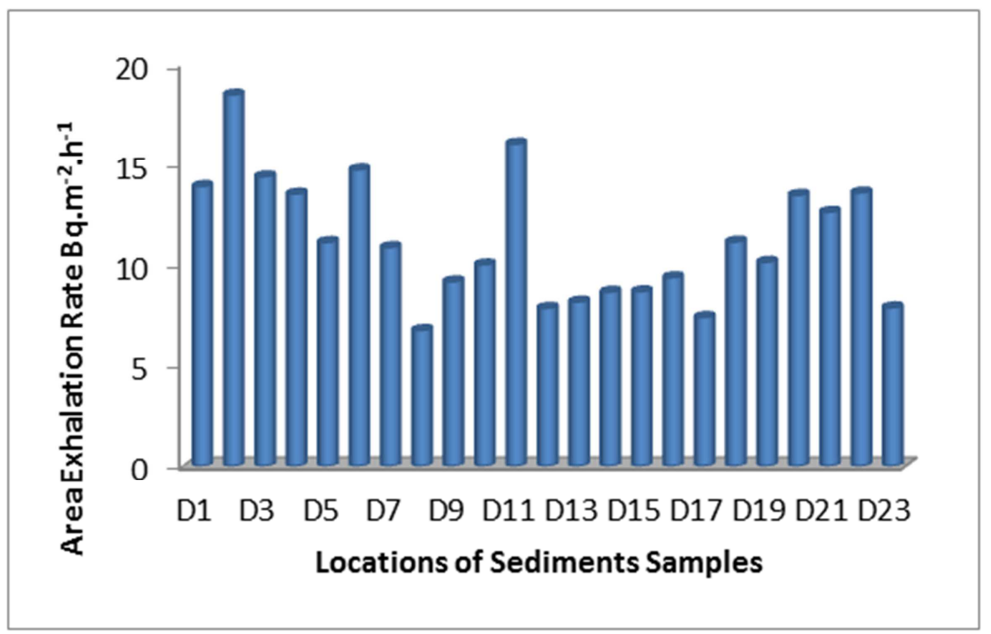

Figure 6. Variation of Area Exhalation Rate at different locations of sediments samples collected from different sites along the Abian beach.

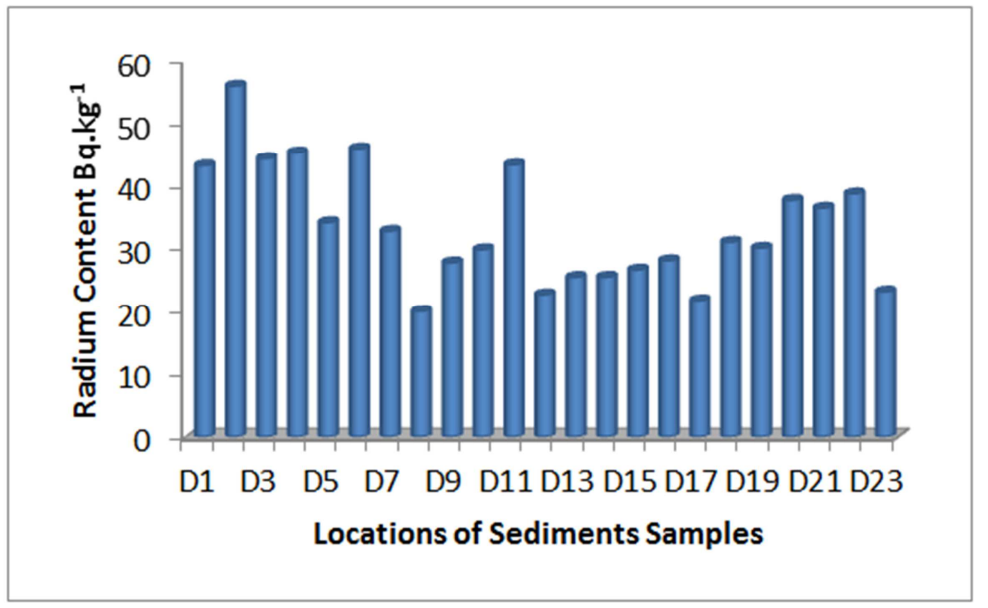

Figure 7. Variation of Radium content at different locations of sediments samples collected from different sites along the Abian beach.

Table 3 compares the activity concentrations of radon in beach sediment samples with other studies in different beaches of the world $[14,23]$. The average value of the radon concentrations in sediment in our study is higher than that in Ras Tanura Saudi Arabia and Thailand, china and Egypt and lower than Saudi Arabia, Khor-Abdulla and Ra's Al-Besha, Iraq and Jordan. On the other hand, it is suitable to conclude that the recorded values are seen to be lower than the hazardous values when compared with other average values

from other national and worldwide works.

Table 3. Comparison of radon concentration level in sediment samples with local and worldwide results.

\begin{tabular}{|c|c|c|}
\hline Country & $\mathrm{C}_{\mathrm{Rn}}\left(\mathrm{Bq} \cdot \mathrm{m}^{-3}\right)$ & Reference \\
\hline Abian beach, Aden Gulf, Yemen & $103.88 \pm 8.80$ & Present study \\
\hline Khor-Abdulla Northern West of the Arabian Gulf - Iraq & $304.3 \pm 79.4$ & {$[10]$} \\
\hline Ra's Al-Besha, Northern west of the Arabian Gulf, Iraq & $400.7 \pm 198$ & [14] \\
\hline Jazan - Saudi Arabia & 88.17 & [21] \\
\hline Ras Tanura - Arabian Gulf - Saudi Arabia (East) & $33 \pm 2.1$ & {$[24]$} \\
\hline Temsah Lake beach in Suez Canal region, Egypt & 29.40 & {$[23]$} \\
\hline Hemavathi River - India & 334.90 & [26] \\
\hline Thailand & $4.5 \pm 0.6$ & [28] \\
\hline Jordan & $918 \pm 214$ & [29] \\
\hline China & 37.64 & [30] \\
\hline
\end{tabular}

\section{Conclusions}

The concentrations of radon in the marine sediment samples collected from the Abian beach have been measured directly; using Alpha guard technique and the radon annual effective doses $E_{R n}\left(\mathrm{mSvy}^{-1}\right)$ have been calculated. The values of radon concentration, effective radium content and the annual effective dose were also determined. The recorded results of our study is representing, the activity concentration 
of radon in the sediments that range between 64.84 to $166.93 \pm 11.85 \mathrm{~Bq} . \mathrm{m}^{-3}$ with mean value $103.88 \pm 8.80 \mathrm{~Bq} . \mathrm{m}^{-3}$.

The radium content in the sediments ranged from 20.01 to $56.06 \mathrm{Bqkg}^{-1}$ with mean value $33.51 \mathrm{Bqkg}^{-1}$, while the area exhalation rate of ${ }^{222} \mathrm{Rn}$ ranged from 6.73 to $18.49 \mathrm{Bqm}^{-2} \mathrm{~h}^{-1}$ with mean value $11.22 \mathrm{Bqm}^{-2} \mathrm{~h}^{-1}$ also the mass exhalation rate of ${ }^{222} \mathrm{Rn}$ ranged from 0.151 to $0.424 \mathrm{Bqkg}^{-1} \mathrm{~h}^{-1}$ with mean value $0.253 \mathrm{Bqkg}^{-1} \mathrm{~h}^{-1}$, respectively.

The mean value of annual effective dose was $2.62 \mathrm{mSv}^{-1}$.

The annual effective dose values were compared with the effective dose limit values recommended by the National Council on Radiation Protection and Measurements (from 1 to $5 \mathrm{mSv} / \mathrm{y}$ ). Results obtained from the current study show that the radon exhalation rates from marine sediments contribute less to the indoor radon. The observed values of effective radium content in sediment samples in the present study are less than the recommended safe according to OECD. The effective radium content and ${ }^{222} \mathrm{Rn}$ exhalation rate are within the average of the world. Thereby it is concluded that sediments of Abian beach, are radiological safe. The results for radon concentrations from the sediments of Abian beach were compared with other literature values and seem to be acceptable and concerning a health hazard for the inhabitant of the town. From these results, a radiological baseline map of the Abian beach can be extracted and used as information reference for the evaluation of any future changes in the radon concentration of the sands of the beach because of any changes in marine sediments.

\section{Conflicts of Interest}

The authors declare no conflict of interest.

\section{References}

[1] Hayder Abdul Wahid Hammood. $2017{ }^{226}$ Ra Concentration and ${ }^{222} \mathrm{Rn}$ Exhalation Rate in Sediments of Euphrates River and Some Its Branches in Thi-Qar Governorate -Southern Iraq, Journal for Natural and Engineering Research and Studies, Vol. 6, No. 11 and 12 P. (95-105).

[2] Al-Khalifa I. J. M. 2006. Polymers track detector used for radon survey in Babel city (Al-Hillah-Iraq), J Basrah Researches (Sciences), 32. Part. 2, 26-30.

[3] Mehmet Fatih Aydin, Ömer Söğüt1.2019. Measurement of radon gas activity concentrations in drinking water in the city center of Adiyaman, Turkey, Radiation Protection and Environment | Volume 42 | Issue 1 \& 2 | January-March \& April-June.

[4] Madureira J, et al. 2016. Radon in indoor air of primary schools: Determinant factors, their variability and effective dose. Environmental Geochemistry Health; 38: 523-33.

[5] Yamada, Y. 2003. Radon exposure and its health effects. Journal of Health Science, 49 (6): 417-422.

[6] Al-Mosuwi, W. H. A. 2006. Environmental radioactivity in Shatt Al-Basrah River banks and Basrah Sport City. PhD. thesis, College of Education, University of Basrah, Iraq.
[7] WHO, 2009. World Health Organization (WHO). WHO Handbook on Indoor Radon: A Public Health Perspective. WHO Press, Geneva, 2009.

[8] UNSCEAR, Report of the United Nation Scientific Committee on the Effect of Atomic Radiation to the General Assembly, (2000).

[9] Oyebanjo O. A., et al. 2012. Natural radionuclides and hazards of sediment samples collected from Osun River in southwestern Nigeria, The pacific journal of science and technology, 13, 2, 391-396.

[10] Munaf Qasim Jaber, Abdul. R. H. Subber and N. H. N. AlHashimi. 2015. Radon Concentrations in the Marine Sediments of Khor-Abdulla Northern West of the Arabian Gulf International Journal of Physics, Vol. 3, No. 6, 239-243.

[11] Onishchenko, A., Zhukovsky, M. and Bastrikov, V. 2015. Calibration system for measuring the radon flux density. Radiation Protection Dosimetry, 164 (4): 582-586.

[12] Catalano, R., Imme, G., Mangano, G., Morelli, D. and Aranzulla, M. 2015. Radon transport laboratory and model study. Radiation Protection Dosimetry, 164 (4): 575-581.

[13] AQUAKIT. Accessory for Radon in Water Measurement in Combination with the Radon Monitor AlphaGUARD, User Manual.

[14] M. Q. Jaber et al. 2017. The concentrations of radon in the marine sediments of Ra's Al-Besha, Northern west of the Arabian Gulf, Mesopot. J. Mar. Sci., 32 (1): 1-8.

[15] S. Harb, A. H. El-Kamel, E. M. Zahran, A. Abbady, and F. A. Ahmed. 2014. Correlation between radon exhalation and radium content in some basalt rocks used as construction material in Aden governorate, south of Yemen, Minia Science Bulletin (Physics Section), Volume 25, pp. 1-11.

[16] S. Harb, N. K. Ahmed, Sahar Elnobi. 2015. Radon exhalation rate and Radionuclides in soil, phosphate, and building materials, Journal of Applied Physics, Volume 7, Issue 2 Ver. I (Mar. - Apr.), PP 41-50.

[17] Zakariya A. Hussein et al. 2013. Study on Radon Emanation from Selected Building Materials in Iraqi Kurdistan Region, International Journal of Scientific Research Engineering \& Technology, Volume 2 Issue 2 pp. 108-112, May.

[18] Junaidah et al., 2018. The Assessment of Indoor Radon-222 Concentration and Emanation Rate at Gua Penyu, Pahang, Malaysian Journal of Analytical Sciences, Vol. 22, No. 3, 483-490.

[19] ICRP, "radiological protection in medicine" ICRP Publication 105. Ann. ICRP 37 (5) (2007).

[20] International Atomic Energy Agency (IAEA), 2018. Radiation Protection and Safety of Radiation Sources: International Basic Safety Standards. Interim Edition. IAEA, Vienna.

[21] Zarrag Al-Fifi, Entsar H. El-Araby, Hanan Elhaes, 2012. Monitoring of Radon Concentrations in Jazan Beach Soil, Journal of Applied Sciences Research, 8 (2): 823-827.

[22] Fatimh Alshahri, Atef El-Taher and Abd Elmoniem Ahmed Elzain. 2017. Characterization of Radon Concentration and Annual Effective Dose of Soil Surrounding a Refinery Area, Ras Tanura, Saudi Arabia, Journal of Environ Science \& Technology., 10 (6): 311-319. 
[23] S. Fares. 2017. Measurements of natural radioactivity level in black sand and sediment samples of the Temsah Lake beach in Suez Canal region in Egypt, Journal of Radiation Research and Applied Sciences 10, 194-203.

[24] F. Alshahri, A. El-Taher, A. A. Elzain. 2019. Measurement of Radon exhalation rate and annual effective dose from Marine Sediments, Ras Tanura, Saudi Arabia, Using CR-39 Detectors, Romanian Journal of Physics 64, 811.

[25] OECD. Exposure to radiation from the natural activity in building materials. Organization for Economic Co-operation Development. Nuclear Energy Agency. 1979.

[26] C. K. Shivanandappa and N. Yerol, 2017. Indoor Built Environ. doi.org/10.1177/1420326, X16688522.
[27] I. Barnet and P. Pacherova, 2011. Environ. Earth Sci. 63, 551557.

[28] S. Chanyotha, C. Kranrod, R. Kritsananuwata, D. Lane-Smith and W. C. Burnett, 2016. Journal of Environmental Radioactivity, 158-159, 47-55.

[29] M. Y. Atallah, B. A. Al-Bataina and H. Mustafa, 2001. Environmental Geol. 40, 1440-1446.

[30] N. Wang, L. Xiao, C. Li, S. Liu, Y. Huang, D. Liu and M. Peng, 2011. Journal of Nuclear Science Technology. 48 (5), 751-758. 